\title{
ASSESSMENT OF HEAVY METALS CONCENTRATION IN WATER AND EDIBLE TISSUES OF NILE TILAPIA (OREOCHROMIS NILOTICUS) AND (CLARIAS GARIEPINUS) FROM BURULLUS LAKE, EGYPT WITH LIVER HISTOPATHOLOGICAL AS POLLUTION INDICATOR
}

\section{BY}

\author{
FATHI M. EL-SHAER AND AHMED N. ALABSSAWY
}

Department of Zoology, Faculty of Science, Al-Azhar University, Nasr City, Cairo, Egypt. ("CorrespondenceShaer82@gmail.com; Ahmed_alabssawy@yahoo.com)

\section{Abstract}

The study reported water quality and the concentrations of heavy metals $(\mathrm{Cu}, \mathrm{Zn}, \mathrm{Fe}, \mathrm{Ni}, \mathrm{Pb}, \mathrm{Mn}$, $\mathrm{Cd}, \mathrm{Co}, \mathrm{Cr} \& \mathrm{Hg}$ ) in water, muscle and liver of two fish species; Clarias gariepinus (Cat fish) and Oreochromis niloticus (Tilapia fish) obtained from Burullus Lake, Kafr Elsheikh Governorate. These alterations were followed, in the present study, by the occurrence of histological lesions in liver of two fishes collected from the same sites. The results showed that there were high level of the analyzed metals (Fe; 56.63mg/kg, Zn; 28.09mg/kg, Mn; 7.89mg/kg, Pb; 7.87mg/kg, Cr; $5.22 \mathrm{mg} / \mathrm{kg}, \mathrm{Cu}$; $2.82 \mathrm{mg} / \mathrm{kg}$, Co; $2.68 \mathrm{mg} / \mathrm{kg}$ and $\mathrm{Hg} ; 0.0103 \mathrm{mg} / \mathrm{kg}$ ) as $\mathrm{Fe}>\mathrm{Zn}>\mathrm{Mn}>\mathrm{Pb}>\mathrm{Cr}>\mathrm{Cu}>\mathrm{Co}>\mathrm{Hg}$ in C. gariepinus and $(\mathrm{Fe} ; 48.15 \mathrm{mg} / \mathrm{kg}, \mathrm{Zn} ; 25.41 \mathrm{mg} / \mathrm{kg}, \mathrm{Mn} ; 7.14 \mathrm{mg} / \mathrm{kg}, \mathrm{Pb} ; 5.23 \mathrm{mg} / \mathrm{kg}, \mathrm{Cu}$; $1.91 \mathrm{mg} / \mathrm{kg} \& \mathrm{Hg} ; 0.0074 \mathrm{mg} / \mathrm{kg}$ ) as $\mathrm{Fe}>\mathrm{Zn}>\mathrm{Mn}>\mathrm{Pb}>\mathrm{Cu}>\mathrm{Hg}$ in O. niloticus sample compared to WHO standard. So, fish in some sites of Burullus Lake may be not safe for human consumption.

Keywords: Burullus Lake, Clarias gariepinus, Oreochromis niloticus, Histopathology, Heavy metals.

\section{Introduction}

Pollution of the aquatic environment by inorganic and organic chemicals is a major factors posing serious threat to the survival of aquatic organisms including fish. The Egypt's northern Delta Lakes include Lake Edku, Lake Borollus, Lake Manzala, and Lake Mariut. These Lakes are situated on the Mediterranean Coast of the Delta and cover about $6 \%$ of the non-desert surface area of Egypt. The Lakes are an important natural resource for fish production in Egypt (GARFD, 2013). Lake Burullus is shallow slightly brackish water situated along the Egyptian Mediterranean Sea coasts (Said et al, 2008).

In aquatic ecosystem, heavy metals are considered as the most important pollutants, since they are present throughout the ecosystem and are detectable in critical amounts. Essential metals such as $\mathrm{Cu}, \mathrm{Zn}$ and $\mathrm{Fe}$ have normal physiological regulatory functions (Hogstrand and Haux, 2001), but may bioaccumulate and reach toxic levels. Nonessential metals are usually potent toxins and their bioaccumulation in tissues lead to intoxication, decreased fertility, tissue dam- age and dysfunction of a variety of organs (Ribeiro et al, 2000; Damek-Proprawa, and Sawicka-Kapusta, 2003).

Heavy metals are non-biodegradable and once discharged into water bodies, they can either be adsorbed on sediment particles or accumulated in aquatic organisms. Fish may absorb dissolved elements and heavy metals from surrounding water and food, which may accumulate in various tissues in significant amounts that reported by (EL-Saieed, and Abdel-Whahed, 1995) and are eliciting toxicological effects at critical targets. Also, fish may accumulate significant concentrations of metals even in waters in which those metals are below the limit of detection in routine water samples (Barak and Mason, 1990), therefore, fish might prove a better material for detecting metals contaminating the water ecosystems. Fish living in polluted waters tend to accumulate heavy metals in their tissues (Nayar et al, 2007). Generally, accumulation depends on metal concentration, time of exposure, way of metal uptake, environmental conditions (water temperature, $\mathrm{PH}$, hardness, salinity) and intrinsic factors such as fish age and feeding habits. 
Various metals show different affinity to fish tissues. Most of these metals accumulate mainly in liver, kidney and gills. Fish muscles, compared to the other tissues; usually contain the lowest levels of metals. Accumulation of heavy metals in various organs of fish may cause structural lesions and functional disturbances (Barbara and Malgorzata, 2006). Gills, liver and kidneys are commonly the primary target organs for pollution. Histopathological lesions and increase in size were determined in various fish exposed to heavy metals (Alazemi et al, 1996).

The present study aimed to determine metals concentrations $(\mathrm{Cu}, \mathrm{Zn}, \mathrm{Fe}, \mathrm{Ni}, \mathrm{Pb}, \mathrm{Mn}$, $\mathrm{Cd}, \mathrm{Co}, \mathrm{Cr} \& \mathrm{Hg}$ ) in water, muscles and liver tissues of Clarias gariepinus \& Oreochromis niloticus obtained from Burullus Lake.

\section{Material and Methods}

Study Area: Lake Burullus lies between longitude $30^{\circ} 33^{\circ}-31^{\circ} 07^{\circ} \mathrm{E}$ and latitude $31^{\circ}$ $22^{`}-31^{\circ} 26^{`} \mathrm{~N}$. on the eastern side of the Rosetta Branch of the River Nile, about $60 \mathrm{~km}$ east of Rosetta and $70 \mathrm{~km}$ west of Damietta Branch (Said et al, 2008). The lake receives water from two main sources; drains and the lake-sea connection. Drained water is discharged via seven drains and the Brembal canal, which connects the lake to Rosetta Estuary. Seawater inflow and drained water play a predominant role in hydrographic and chemical composition of the lake, which is connected to the sea by a narrow $(171 \mathrm{~m}$ width) passage; Al-Burg by Boughaz Al-Burullus (Garfd, 2013). Fish and water were monthly collected in summer 2016 at 3 selected sites.

Table 1: Longitude and Latitude of sample collection sites at Burullus Lake, Egypt.

\begin{tabular}{|c|c|c|c|}
\hline Site No. & Site Name & Longitude & Latitude \\
\hline 1 & Mastroo & $28^{\circ} 34^{\prime} 77.00$ east & $34^{\circ} 83^{\prime} 69.50$ north \\
\hline 2 & Sedi_yousef & $26^{\circ} 87^{\prime} 13.00$ east & $34^{\circ} 79^{\prime} 43.70$ north \\
\hline 3 & Elberka Elgharbia & $27^{\circ} 40^{\prime} 05.00$ east & $34^{\circ} 77^{\prime} 96.20$ north \\
\hline
\end{tabular}

Fish were collected by fishermen nets put in containers containing ice for preservation to reaching the laboratory for analysis each fish was measured and weighted using scale and directly dissected to take different samples from the organ we need to study. Tilapia, Oreochromis niloticus the weights vary between 110.96-177.32gm, the length vary between $18.54-23.87 \mathrm{~cm}$ and for Clarias gariepinus the length $19.23-29.76 \mathrm{~cm}$ and the weights vary between 195.34-295.10gm.

ICP analysis by digestion method: 1 - 10 ml Conc. $\mathrm{HNO}_{3}$ was added to $1 \mathrm{gm}$. of fresh tissue then was digested using Microwave Digestion System (MILESTONE, ETHOS EASY model: ACT36, Made in Italy). 2The digested Sample then was diluted till 25 $\mathrm{ml}$ using deionized water. Concentration of $\mathrm{Cu}, \mathrm{Zn}, \mathrm{Fe}, \mathrm{Ni}, \mathrm{Pb}, \mathrm{Mn}, \mathrm{Cd}, \mathrm{Co}, \mathrm{Cr} \& \mathrm{Hg}$ were determined in fish samples. The analyses of metals in fish and liver tissue will analyzed after digestion but water samples were analyzed directly (Jayakumar and Subburaj, 2017).
All measurements by ICP analysis method were as follow: 1- Serial dilutions were prepared from a stock solution contains 1000 $\mathrm{mg} / \mathrm{L}$ of Copper, Zinc, Iron, Nickel, Lead, manganese, Cadmium, Cobalt, Chromium and Mercury with the following concentrations $(0.5,1,1.5,2,2.5,3,3.5,4 \mathrm{mg} / \mathrm{L})$ using Deionized water. 2- Standards were measured at ICP (Perkin Elmer Model: Optima 7000 DV Made in Germany) to build up Standard curve. 3- Curve was used to measure the samples Conc. by WINLAB32 Software.

Hepatosomatic index (HSI) was calculated (Schreck and Moyle, 1990) as: HSI = liver weight $(\mathrm{g}) /$ fish weight $(\mathrm{g}) \mathrm{x} 100$

The water samples collected directly from the sampling areas at $50 \mathrm{~cm}$ depth from the water surface using $500 \mathrm{ml}$ plastic bottles for analysis. Some tests were measured at the field including temperature, salinity, electronic conductivity $(\mathrm{EC})$, transparency $(\mathrm{cm})$, which was determined by using Secchi-disc, $\mathrm{pH}$ and dissolved oxygen (DO) were deter- 
mined by YSI-Operations Manual Eco Sense Portable Conductivity, Salinity and Temperature Instrument. Model: EC300A, Serial NO: JC00293. After measuring the plastic bottles preserved immediately in an ice-box and transported immediately to the laboratory for tests such as Ammonia $\left(\mathrm{NH}_{3}\right)$, Nitrite $\left(\mathrm{NO}_{2}\right)$, Nitrate $\left(\mathrm{NO}_{3}\right)$, phosphate $\left(\mathrm{PO}_{4}\right)$ and some Heavy metals concentration were determined (HACH DR/2010) portable data logging spectrophotometer, Procedures manual for water, wastewater and seawater. Serial No.: 990400012932, P/N: 4930060, except phosphate was determined by LaMotte low range phosphate kit, Using low range comparator with range 0.0-2.0 PPM; CODE 3121-02; Record as ppm Orthophosphate.

Histological investigations: Liver of tilapia and catfish were collected from the selected sites. The organs were fixed in neutral formalin solution, dehydrated, embedded in paraffin wax and sectioned at 4-7 $\mu \mathrm{m}$. Slides were stained with hematoxylin and eosin and examined microscopically (Osman et al, 2008).

Statistical analysis: Data were computerized and analyzed using using SAS Version 9 statistical package (SAS, 2002). Mean of treatments were compared by Duncan multiple range test (Duncan, 1955).

\section{Results}

Table: 2: Effect of heavy metals on hepato-somatic index (HSI \%) of O. niloticus from locations $1,2 \& 3$.

\begin{tabular}{|c|c|c|c|c|}
\hline Site No. & No. of fishes & minimum & maximum & Mean \pm SE \\
\hline 1 & 9 & 1.12 & 2.66 & $1.79 \pm 0.16$ \\
\hline 2 & 9 & 0.70 & 1.37 & $0.95 \pm 0.08^{* * *}$ \\
\hline 3 & 9 & 0.99 & 2.11 & $1.41 \pm 0.13^{\text {N.S }}$ \\
\hline
\end{tabular}

${ }^{\text {N.S }}$ Not significant, *significant $\mathrm{P}<0.05$, ** highly significant $\mathrm{P}<0.001$, Site 1: Mastroo, Site2: Sedi-Yousef, and Site 3: Elberka Elgharbia, ppm= part per million

Table 3: Effect of heavy metals on hepato- somatic index (HSI \%) of Clarias gariepinus from locations 1,2 \& 3.

\begin{tabular}{|c|c|c|c|c|}
\hline Site No. & No. of fishes & minimum & maximum & Mean \pm SE \\
\hline 1 & 9 & 0.88 & 1.83 & $1.33 \pm 0.10$ \\
\hline 2 & 9 & 0.92 & 1.42 & $1.16 \pm 0.06^{*}$ \\
\hline 3 & 9 & 1.07 & 1.47 & $1.22 \pm 0.04^{\text {N.S }}$ \\
\hline
\end{tabular}

O. niloticus showed ascending order of HIS value as: Mastroo (1.79\%) > Elberka El-gharbia $(1.41 \%)>$ Sedi-Yousef $(0.95 \%)$. HSI of $C$. gariepinus showed same sequence in site $1,3 \& 2(1.33,1.22 \& 1.16 \%)$ respectively (Tabs. $2 \& 3$ ). Independent t-test of $O$. niloticus showed HSI of site 1 as control and others showed highly significance $(\mathrm{P}<$ 0.001 ) between sites $1 \& 2$, but without significance $(\mathrm{P}<0.05)$ between sites $1 \& 3$. $C$. gariepinus HSI value showed significance between sites $1 \& 2(\mathrm{P}<0.05)$, but without significance $(\mathrm{P}<0.05)$ between sites $1 \& 3$.

Table 4: Physicochemical characteristics of water at sites of locations $1,2 \& 3$.

\begin{tabular}{|l|c|c|c|}
\hline Parameters & Site 1 & Site 2 & Site 3 \\
\hline \multicolumn{3}{|c|}{ A- Physical Parameters } \\
\hline 1. Temperature (C) & $27.77 \pm 0.50$ & $29.23 \pm 0.88^{\text {N.S }}$ & $28.32 \pm 0.87^{\text {N.S }}$ \\
\hline 2. Salinity (S\%) & $1.25 \pm 0.12$ & $0.88 \pm 0.08^{*}$ & $1.09 \pm 0.21^{\text {N.S }}$ \\
\hline 3.Electrical Conductivity (EC) (mSiemens/cm) & $2.58 \pm 0.04$ & $1.85 \pm 0.03^{*}$ & $2.30 \pm 0.08^{\text {N.S }}$ \\
\hline 4. Transparency (cm) & $30.00 \pm 0.58$ & $34.00 \pm 0.58^{*}$ & $28.00 \pm 0.58^{\text {N.S }}$ \\
\hline \multicolumn{3}{|c|}{ B- Chemical Parameters } \\
\hline 1. pH & $7.60 \pm 0.52$ & $8.12 \pm 0.22^{\text {N.S }}$ & $8.60 \pm 0.62^{\text {N.S }}$ \\
\hline 2. Dissolved $\mathrm{Oxygen} \mathrm{(DO)}(\mathrm{mg} / \mathrm{L})$ & $9.22 \pm 0.22$ & $7.21 \pm 0.26^{*}$ & $8.15 \pm 0.13^{*}$ \\
\hline 3. Ammonia $(\mathrm{NH})(\mathrm{mg} / \mathrm{L})$ & $0.45 \pm 0.03$ & $0.75 \pm 0.08^{*}$ & $0.60 \pm 0.04^{\text {N.S }}$ \\
\hline 4. Nitrite $\left(\mathrm{NO}_{2}\right)(\mathrm{mg} / \mathrm{L})$ & $0.05 \pm 0.02$ & $0.32 \pm 0.02^{*}$ & $0.25 \pm 0.03^{*}$ \\
\hline 5. Nitrate $\left(\mathrm{NO}_{3}\right)(\mathrm{mg} / \mathrm{L})$ & $0.24 \pm 0.08$ & $0.64 \pm 0.04^{*}$ & $0.48 \pm 0.06^{\text {N.S }}$ \\
\hline 6. Phosphate $\left(\mathrm{PO}_{4}\right)(\mathrm{mg} / \mathrm{L})$ & $0.37 \pm 0.03$ & $0.79 \pm 0.04^{*}$ & $0.49 \pm 0.03^{*}$ \\
\hline
\end{tabular}

Water Quality: Physicochemical characteristics of water collected from the three sites in western area of Burullus Lake, including: Mastroo, Sedi-Yousef \& Elberka Elgharbia. 
Physical parameters showed a descending order of water temperature as: Sedi-Yousef $\left(29.23^{\circ} \mathrm{C}\right)>$ Elberka-Elgharbia $\left(28.32^{\circ} \mathrm{C}\right)>$ Mastroo $\left(27.77^{\circ} \mathrm{C}\right)$. The water salinity as follows: Mastroo (1.25\%) > Elberka Elgharbia $(1.09 \%)>$ Sedi-Yousef $(0.88 \%)$.

The highest conductivity value $(2.58 \mathrm{~m}$ Siemens/cm) was recorded at Mastroo station while the lowest one was $(1.85 \mathrm{~m} \mathrm{Sie}$ mens $/ \mathrm{cm}$ ) recorded at Sedi-Yousef station. In spite of the highest transparency value $(34.00 \mathrm{~cm})$ that was recorded at Sedi-Yousef station while the lowest one $(28.00 \mathrm{~cm})$ that was recorded at Elberka Elgharbia station.

Chemical parameters: $\mathrm{pH}$ values ranged from 7.60 at Mastroo to 8.60 at Elberka Elgharbia, while the highest dissolved oxy-

Table 5: Heavy metals concentrations in water samples collected from sites 1, 2 \& 3 of Burullus Lake.

\begin{tabular}{|l|c|c|c|}
\hline Parameters & Site 1 & Site 2 & Site 3 \\
\hline $\mathrm{Cu}(\mathrm{ppm})$ & $0.0047 \pm 0.0015$ & $0.0070 \pm 0.0010^{\mathrm{NSS}}$ & $0.0667 \pm 0.0321^{*}$ \\
\hline $\mathrm{Zn}(\mathrm{ppm})$ & $0.0081 \pm 0.0006$ & $0.0156 \pm 0.0010^{*}$ & $0.0136 \pm 0.0011^{*}$ \\
\hline $\mathrm{Fe}(\mathrm{ppm})$ & $0.4233 \pm 0.0512$ & $0.8320 \pm 0.0648^{*}$ & $0.6240 \pm 0.0340^{*}$ \\
\hline $\mathrm{Ni}(\mathrm{ppm})$ & $0.0015 \pm 0.0005$ & $0.0058 \pm 0.0004^{*}$ & $0.0038 \pm 0.0003^{*}$ \\
\hline $\mathrm{Pb}(\mathrm{ppm})$ & $0.0381 \pm 0.0096$ & $0.0600 \pm 0.0033^{*}$ & $0.0552 \pm 0.0060^{\mathrm{N.S}}$ \\
\hline $\mathrm{Mn}(\mathrm{ppm})$ & $0.0438 \pm 0.0079$ & $0.0525 \pm 0.0045^{*}$ & $0.0560 \pm 0.0053^{*}$ \\
\hline $\mathrm{Cd}(\mathrm{ppm})$ & $0.0017 \pm 0.0002$ & $0.0029 \pm 0.0009^{\mathrm{N} . S}$ & $0.0016 \pm 0.0003^{\mathrm{N.S}}$ \\
\hline $\mathrm{Co}(\mathrm{ppm})$ & $0.0002 \pm 0.0001$ & $0.0017 \pm 0.0002^{* *}$ & $0.0013 \pm 0.0001^{*}$ \\
\hline $\mathrm{Cr}(\mathrm{ppm})$ & $0.0029 \pm 0.0008$ & $0.0062 \pm 0.0004^{*}$ & $0.0051 \pm 0.0006^{*}$ \\
\hline $\mathrm{Hg}(\mathrm{ppm})$ & $0.0003 \pm 0.0001$ & $0.0008 \pm 0.0001^{*}$ & $0.0005 \pm 0.0001^{\mathrm{N.S}}$ \\
\hline
\end{tabular}

The values of the selected metals in the Burullus Lake water were lower than the permissible limits nearly in all examined sites. Iron, Lead and Manganese concentrations were higher than the permissible limit in the in site $2 \&$ site 3 . Mercury levels were higher than the permissible limits in all sites according to the values allowed (Serov et al, 2012; WHO, 2012).

No Ni was detected in water of all sites. Also, $\mathrm{Cr}$ was not detected in water of Site 1 but its levels in water of sites $2 \& 3$ were 0.006 and 0.005 ppm respectively. However, the concentration of $\mathrm{Pb}$ in water of swite 2 is higher (nearly 2 times) than that of the control (site 1). Levels of $\mathrm{Zn}$ in water of sites 2 $\& 3$ and $\mathrm{Fe}$ in water of site 2 were highly gen value $(9.22 \mathrm{mg} / \mathrm{L})$ was recorded at Mastroo and lowest value was $(7.21 \mathrm{mg} / \mathrm{L})$ recorded at Sedi-Yousef. The highest values of ammonia, nitrite, nitrate and phosphorus was recorded at Sedi-Yousef station as $(0.75,0.32,0.64 \& 0.79 \mathrm{mg} / \mathrm{L})$ respectively but the lowest one was recorded at Mastroo as $(0.45,0.05,0.24 \& 0.37 \mathrm{mg} / \mathrm{L})$ respectively So, this station was control area.

The levels of dissolved oxygen, ammonia, nitrite, nitrate and phosphate in water of site 2 were significant $(\mathrm{P}<0.05)$ compared to the control in site 1 . The concentration of dissolved oxygen, nitrite and phosphate in water of site 3 were significant when compared to control in site 1 . significantly increased when compared to control (site 1) (Tab. 5).

The heavy metal concentrations in the fish samples decreased in the sequence for the muscle of $O$. niloticus as $\mathrm{Fe}>\mathrm{Zn}>\mathrm{Mn}>\mathrm{Pb}$ $>\mathrm{Cu}>\mathrm{Hg}$ in all sites and for the muscle of $C$. gariepinus as $\mathrm{Fe}>\mathrm{Zn}>\mathrm{Pb}>\mathrm{Mn}>\mathrm{Cr}>\mathrm{Co}$ $>\mathrm{Cu}>\mathrm{Hg}$ in site (1) but in sites (2 and 3) as $\mathrm{Fe}>\mathrm{Zn}>\mathrm{Mn}>\mathrm{Pb}>\mathrm{Cr}>\mathrm{Cu}>\mathrm{Co}>\mathrm{Hg}$.

Concentrations of $\mathrm{Fe}$ and $\mathrm{Mn}$ in muscles of C. gariepinus from Site 2 are highly significant increased compared to control. Also, the levels of $\mathrm{Zn}$ and $\mathrm{Hg}$ in muscles of $O$. niloticus from site 2 are highly significant increased compared to that of the control (Tab. 6). 
Table 6: Heavy metals concentrations in edible tissues of Oreochromis niloticus and Clarias gariepinus collected sites 1, 2 \& 3 of Burullus Lake, Egypt.

\begin{tabular}{|c|c|c|c|c|}
\hline Parameters & Fish Type & Site1 & Site 2 & Site 3 \\
\hline \multirow{2}{*}{$\mathrm{Cu}(\mathrm{ppm})$} & O. niloticus & $0.99 \pm 0.12$ & $1.91 \pm 0.29^{*}$ & $1.80 \pm 0.35^{*}$ \\
\hline & C. gariepinus & $1.07 \pm 0.13$ & $2.82 \pm 0.33^{*}$ & $2.31 \pm 0.58^{*}$ \\
\hline \multirow{2}{*}{$\mathrm{Zn}(\mathrm{ppm})$} & O. niloticus & $21.19 \pm 0.18$ & $25.41 \pm 0.30^{* *}$ & $23.74 \pm 1.01^{*}$ \\
\hline & C. gariepinus & $24.78 \pm 0.65$ & $28.09 \pm 0.34^{*}$ & $29.07 \pm 0.26^{*}$ \\
\hline \multirow{2}{*}{$\mathrm{Fe}(\mathrm{ppm})$} & O. niloticus & $42.00 \pm 0.30$ & $48.15 \pm 0.67^{*}$ & $45.96 \pm 0.85^{*}$ \\
\hline & C. gariepinus & $49.99 \pm 0.30$ & $56.63 \pm 0.52^{* *}$ & $53.15 \pm 0.19^{*}$ \\
\hline \multirow{2}{*}{$\mathrm{Ni}(\mathrm{ppm})$} & O. niloticus & 0 & 0 & 0 \\
\hline & C. gariepinus & 0 & 0 & 0 \\
\hline \multirow{2}{*}{$\mathrm{Pb}(\mathrm{ppm})$} & O. niloticus & $3.71 \pm 0.51$ & $5.23 \pm 0.30^{*}$ & $4.94 \pm 0.08^{*}$ \\
\hline & C. gariepinus & $6.63 \pm 0.36$ & $7.87 \pm 0.19^{*}$ & $5.86 \pm 0.49^{*}$ \\
\hline \multirow{2}{*}{ Mn (ppm) } & O. niloticus & $5.41 \pm 0.49$ & $7.14 \pm 0.32^{*}$ & $6.01 \pm 0.21^{\text {N.S }}$ \\
\hline & C. gariepinus & $4.98 \pm 0.19$ & $7.89 \pm 0.30^{* *}$ & $6.53 \pm 0.48^{*}$ \\
\hline \multirow{2}{*}{$\mathrm{Cd}(\mathrm{ppm})$} & O. niloticus & 0 & 0 & 0 \\
\hline & C. gariepinus & 0 & 0 & 0 \\
\hline \multirow{2}{*}{ Co (ppm) } & O. niloticus & 0 & 0 & 0 \\
\hline & C. gariepinus & $1.49 \pm 0.49$ & $2.68 \pm 0.24^{*}$ & $1.79 \pm 0.17^{\text {N.S }}$ \\
\hline \multirow{2}{*}{$\mathrm{Cr}(\mathrm{ppm})$} & O. niloticus & 0 & 0 & 0 \\
\hline & C. gariepinus & $3.52 \pm 0.35$ & $5.22 \pm 0.08^{*}$ & $4.46 \pm 0.18^{*}$ \\
\hline \multirow{2}{*}{$\mathrm{Hg}(\mathrm{ppm})$} & O. niloticus & $0.0059 \pm 0.0002$ & $0.0074 \pm 0.0001^{* *}$ & $0.0067 \pm 0.0002^{*}$ \\
\hline & C. gariepinus & $0.0096 \pm 0.0002$ & $0.0103 \pm 0.0002^{*}$ & $0.0105 \pm 0.0004^{N . S}$ \\
\hline
\end{tabular}

Table 7: Heavy metals concentrations in liver of Oreochromis niloticus and Clarias gariepinus collected from sites $1,2 \& 3$ of Burullus Lake, Egypt.

\begin{tabular}{|c|c|c|c|c|}
\hline Parameters & Fish type & Site 1 & Site 2 & Site 3 \\
\hline \multirow{2}{*}{$\mathrm{Cu}(\mathrm{ppm})$} & O. niloticus & $11.37 \pm 0.55$ & $16.54 \pm 0.62^{*}$ & $13.11 \pm 0.18^{*}$ \\
\hline & C. gariepinus & $13.33 \pm 0.69$ & $20.31 \pm 0.52^{*}$ & $17.37 \pm 0.33^{*}$ \\
\hline \multirow{2}{*}{$\mathrm{Zn}(\mathrm{ppm})$} & O. niloticus & $33.40 \pm 0.53$ & $38.08 \pm 0.17^{* *}$ & $35.61 \pm 0.47^{*}$ \\
\hline & C. gariepinus & $36.60 \pm 0.32$ & $41.13 \pm 0.69^{*}$ & $37.46 \pm 0.34^{\mathrm{N} . S}$ \\
\hline \multirow{2}{*}{$\mathrm{Fe}(\mathrm{ppm})$} & O. niloticus & $57.23 \pm 0.71$ & $63.22 \pm 1.00^{*}$ & $59.51 \pm 0.61^{*}$ \\
\hline & C. gariepinus & $67.15 \pm 0.27$ & $84.40 \pm 0.64^{* *}$ & $73.25 \pm 0.39^{*}$ \\
\hline \multirow{2}{*}{$\mathrm{Ni}(\mathrm{ppm})$} & O. niloticus & 0 & 0 & 0 \\
\hline & C. gariepinus & 0 & 0 & 0 \\
\hline \multirow{2}{*}{$\mathrm{Pb}(\mathrm{ppm})$} & O. niloticus & $7.31 \pm 0.54$ & $8.99 \pm 0.42^{*}$ & $10.85 \pm 0.84^{*}$ \\
\hline & C. gariepinus & $10.46 \pm 0.40$ & $11.35 \pm 0.47^{*}$ & $9.41 \pm 0.14^{*}$ \\
\hline \multirow{2}{*}{ Mn (ppm) } & O. niloticus & $9.15 \pm 0.27$ & $12.41 \pm 0.60^{*}$ & $11.46 \pm 0.48^{*}$ \\
\hline & C. gariepinus & $8.36 \pm 0.47$ & $13.61 \pm 0.36^{* * *}$ & $10.57 \pm 0.25^{*}$ \\
\hline \multirow{2}{*}{ Cd (ppm) } & O. niloticus & 0 & 0 & 0 \\
\hline & C. gariepinus & 0 & 0 & 0 \\
\hline \multirow{2}{*}{ Co (ppm) } & O. niloticus & $0.95 \pm 0.09$ & $1.71 \pm 0.32^{*}$ & $1.14 \pm 0.09^{* * *}$ \\
\hline & C. gariepinus & $1.63 \pm 0.43$ & $2.29 \pm 0.17^{\mathrm{N} . \mathrm{S}}$ & $1.96 \pm 0.11^{\text {N.S }}$ \\
\hline \multirow{2}{*}{$\mathrm{Cr}(\mathrm{ppm})$} & O. niloticus & 0 & 0 & 0 \\
\hline & C. gariepinus & $9.43 \pm 0.37$ & $11.77 \pm 0.21^{*}$ & $11.20 \pm 0.16^{*}$ \\
\hline \multirow{2}{*}{$\mathrm{Hg}$ (ppm) } & O. niloticus & $0.0107 \pm 0.0004$ & $0.0128 \pm 0.0001^{*}$ & $0.0116 \pm 0.0003^{*}$ \\
\hline & C. gariepinus & $0.0196 \pm 0.0002$ & $0.0249 \pm 0.0001^{* *}$ & $0.0228 \pm 0.0003^{*}$ \\
\hline
\end{tabular}

Heavy metal concentrations in the fish samples decreased in the sequence for the liver of $O$. niloticus as $\mathrm{Fe}>\mathrm{Zn}>\mathrm{Cu}>\mathrm{Mn}>\mathrm{Pb}$ $>\mathrm{Co}>\mathrm{Hg}$ in all sites and for the liver of $C$. gariepinus as $\mathrm{Fe}>\mathrm{Zn}>\mathrm{Cu}>\mathrm{Pb}>\mathrm{Cr}>\mathrm{Mn}$ $>\mathrm{Co}>\mathrm{Hg}$ in site 1 but in site 2 as $\mathrm{Fe}>\mathrm{Zn}>$ $\mathrm{Cu}>\mathrm{Mn}>\mathrm{Cr}>\mathrm{Pb}>\mathrm{Co}>\mathrm{Hg}$ and site 3 as
$\mathrm{Fe}>\mathrm{Zn}>\mathrm{Cu}>\mathrm{Cr}>\mathrm{Mn}>\mathrm{Pb}>\mathrm{Co}>\mathrm{Hg}$. Concentrations of $\mathrm{Fe}, \mathrm{Mn} \& \mathrm{Hg}$ in liver of C. gariepinus from Site 2 were highly significantly increased when compared to control. The levels of Co in liver of O. niloticus from site 3 were significantly highly increased when compared to control (Tab. 7), 
Histopathology changes were detected in liver tissue of $O$. niloticus and $C$. gariepinus that were collected from different selected sites of Burullus Lake, Egypt. Significant differences in the degree of such changes were recorded according to the degree of pollution in the site. Photomicrograph of the liver tissue (Fig. 2A \& F) showed the histopathological changes in $O$. niloticus collected from site 2 (Sedi-Yousef) including irregular arrangements of hepatocytes, vacuolation (v), congested blood vessels (CBV), necrosis $(\mathrm{N})$ of cytoplasm and hemolysis $(\mathrm{H})$ (Fig. 2A). In C. gariepinus severe histopathological effect in liver tissue represented by abnormal appearance, fibrosis $(\mathrm{F})$, invading by lymphocytes or polymorph leukocytes (L), some necrotic areas were encapsulated by fibrous layers and packed with aggregated lymphocytes forming neoplastic cysts (C) (Fig. 2F). Fishes from site 3 (Elberka Elgharbia) where $O$. niloticus showed some histopathological lesions represented by hemolysis $(\mathrm{H})$ in central vein with infiltration of leukocytes (L) (Fig. 2 C), while in C. gariepinus were more affected with pollution that appeared as vasodilatation in central vein, degeneration of hepatocytes giving necrotic and vacuolated areas (V) in hepatic cells and infiltration of lymphocytes (Fig. 2D). At site 1(Mastroo), O. niloticus samples collected showed no histopathological lesion in liver tissue and hepatic cells appeared normal, the parenchymal cells arranged to form a lattice network and interspaces were of thin strip with sparse connective tissue. Sinusoids made continuous communication as being converging into the central vein (CV) (Fig. 2E), Histopathological changes found the liver of $C$. gariepinus showed dilation of the central vein accompanied by blood congestion (CBV) and invading of leukocytes infiltration around the central vein (L) (Fig. 2B).

Table 8: Histopathological lesions in liver tissue of $O$. niloticus and $C$. gariepinus collected from different selected sites of Burullus Lake, Egypt.

\begin{tabular}{|c|c|c|c|c|c|c|}
\hline \multirow{2}{*}{$\begin{array}{c}\text { Histopathological changes in } \\
\text { liver }\end{array}$} & \multicolumn{3}{|c|}{ O. niloticus } & \multicolumn{3}{c|}{ C. gariepinus } \\
\cline { 2 - 7 } & Site 1 & Site 2 & Site 3 & Site 1 & Site 2 & Site 3 \\
\hline Infiltration of leukocytes & - & - & + & + & + & + \\
\hline Vasodilation in central vein & - & - & - & - & - & + \\
\hline Degeneration of hepatocytes & - & - & - & - & + & - \\
\hline Necrotic and vacuolated area & - & + & - & - & + & + \\
\hline Congested blood vessels & - & + & - & + & - & - \\
\hline Hemolysis & - & + & + & - & - & - \\
\hline Fibrosis & - & - & - & - & + & + \\
\hline Neoplastic cysts & - & - & - & - & + & - \\
\hline
\end{tabular}

Histopathological detected lesions in the liver tissue of both $O$. niloticus and C. gariepinus collected from different three sites, result showed that site (1) was less polluted than site (3), and site (2) showed highest pollution (Tab. 8).

\section{Discussion}

The present results showed that most of the physical and chemical parameters were significantly highly polluted in water collected from site 2 compared to other sites.

One of the most important functions of liver is to clean pollutants from the blood coming from the intestine, so it is considered as indicator of aquatic environmental pollu- tion (Soufy et al, 2007; Sandstrom et al, 2005) suggested that HSI was a biomarker that indicated the status of feeding and metabolism. The liver size indicated the high of metabolic activity while the small size of the liver could be caused by lack of food. According to Vander Oost et al, (2003) HIS were significantly decreased when exposed to organic pollutants exposure and heavy metals, this decrease was likely caused by the influence of the food limitations and the stress factors.

The HSI value of $O$. niloticus and $C$. gariepinus in sites $2 \& 3$ was lower than in control. This suggested that heavy metals expo- 
sure resulted in the low of average HSI value. The low value of HSI might be occurred when the waters polluted by heavy metals, then these heavy metals were absorbed through the epithelial membrane, especially the gills. These were carried to the liver by the blood, resulting in the accumulation of heavy metals in the liver; in addition to the heavy metal accumulation in the liver would result in malfunction of enzymes because of a bonding of heavy metal with sulfhydryl ($\mathrm{SH})$ group on the enzymes, thereby disrupting body's metabolism and causing fish liver became low so that HSI value decreased/low (Katzung, 2007). Given the heavy metals were toxic and carcinogenic, then the accumulation of heavy metals in the liver would damage the liver tissue, so that the fish liver went to have swelling (hepatomegaly) first, but if the level of damage was getting worse due to the greater accumulation of heavy metals in the liver, then the liver would suffer necrosis and cirrhosis (Camargo and Martinez, 2007; Jayakumar and Subburaj, 2017). Cirrhosis would decrease the liver size / shrinkage. The size of a small liver would lead to severe liver became low so that the value of HSI low/declining. The present results agreed with others who studied the effects of pollutants on fish (Ptashynski, 2002; Fanta, 2003; Olojo, 2005).

In the present study, most of the detected physical and chemical parameters were significantly higher in the water collected from Sedi-Yousef (site 2) and Elberka-Elgharbia (site 3) comparing to control (site 1).

The physico-chemical parameters were paramount, important and influenced by natural and manmade activities. They also depended upon the depth of water body and ecological conditions of ecosystem. Dissolved oxygen (DO) is an important water parameter indicating the quality of water and organic production in lake (Wetzel and Likens, 2006). Survival of aquatic flora and fauna especially fish, depends on the dissolved oxygen in water. Most of the detected physical and chemical parameters were sig- nificantly higher in water samples collected from sites $2 \& 3$ (Sedi-Yousef and El-berkaElgharbia) compared to site 1 (Mastroo). Thus, the mean values of conductivity, dissolved oxygen (DO), salinity (S\%), ammonia $(\mathrm{NH} 3)$, nitrate $\left(\mathrm{NO}_{3}\right)$, nitrite $\left(\mathrm{NO}_{2}\right)$ and phosphate were higher in the water of SediYousef followed by Elberka-Elgharbia sites compared to Mastroo.

Wang et al, (2011) showed that, NO3 was mainly associated with agriculture activities and nitrites are intermediate products in the nitrification process of ammonia to nitrates and they are toxic to fish which compatible with results of (Abdellhamid et al, 2013). The toxicity of nitrite may be due to the reaction of nitrite with secondary amines to produce the carcinogenic nitrosamine (Ali, 1991). These results agree with that recorded by other investigators including Okbah, (2005) who recorded a high level of nitrite $(0.30-0.32 \mathrm{mg} / \mathrm{L})$ in water of Burullus Lake. So, this can lead to outlets of Brimbal canal which contains fresh water coming from the River Nile with drainage from agricultural drained with artificial nitrogenous fertilizers and effluent from certain industries causing elevation in ammonia nitrate and nitrite sites $2 \& 3$.The increase in ammonia, nitrate and nitrite concentration in the present study agreed with Hereher et al. (2010).

The values of the selected metals in the water of sites $2 \& 3$ were high compared to site 1. Lead, Iron, chromium and mercury concentrations were higher than the permissible limit in the water collected from SediYousef and Elberka-Elgharbia. This showed presence of large quantities of organic and inorganic pollutants, disposal of domestic and industrial effluent in water of Sedi-Yousef and Elberka-Elgharbia. The water of such sites receives large quantities of wastes without sufficient treatments from drain (11) and El Khregeen Pump water station, which agreed with EL-Sadany, (2013) and Eid et al, (2012). Mercury is the widespread environmental pollutant inducing severe alterations in the fish tissues (Sener et al, 2007). 
The liver is major site for its metabolism that caused severe hepatic damages (Knazicka et al, 2013). In the present results, the highest concentrations of all heavy metals were recorded in liver tissues due to strong binding with cysteine residues of metallothionein (MT), which serves as a detoxification mechanism (Yacoub, 2007). MT has high affinities for heavy metals and concentrates and regulates in liver (McCarter and Roch, 1983). Muscles accumulate small amounts of all heavy metals received via circulation. The low accumulation of metals in muscle may be due to lack of their binding affinity with the muscle proteins. The present results showed high elevation in concentrations of $\mathrm{Pb}, \mathrm{Fe}, \mathrm{Zn}, \mathrm{Hg}, \mathrm{Mn} \& \mathrm{Cu}$ than in control in muscles of Tilapia (sites 2 \& 3), also concentrations of $\mathrm{Pb}, \mathrm{Fe}, \mathrm{Zn}, \mathrm{Hg}$, $\mathrm{Mn}, \mathrm{Cr}, \mathrm{Co} \& \mathrm{Cu}$ were more than in control in muscles of Catfish (sites $2 \& 3$ ). These data agreed with Sorensen (1991). Thus, the distribution patterns of $\mathrm{Cu} \& \mathrm{Zn}$ in the Lake water increased in hot seasons where the heavy metals were released from sediments to overlying water affected by high temperature and decomposition of fermented organic matters (Elewa et al, 2001). All the heavy metals contamination was due to new urbanization and agricultural drains as Zaghloul (Sedi-Yousef) pump Istation and El-Hoksa drain nearby (sites $2 \& 3$ ). In the present study, absent of nickel and cadmium in liver and muscles might be due to the fact that industries that produce them not present in Burullus Lake district. These results agreed with others (Elghobashy et al, 2001; Nafea and Zyada, 2015; Saeed and Shaker, 2008).

The present histopathological changes in liver tissue of $O$. niloticus and $C$. gariepinus collected from the selected sites of Burullus Lake showed biomarkers of toxicity in fish organs, a useful indicator of environmental pollution (Peebua et al, 2008). The histological studies gave marked indication of fish abnormalities. So, many histological lesions were detected in liver tissues of $O$. niloticus and $C$. gariepinus. Liver showed degeneration in hepatocytes, necrosis, aggregation of inflammatory cells, dilatation and congestion in blood sinusoid fibrosis hemolysis \& neoplastic cyst. These were attributed to the toxic effects of pollutants on liver (Gingerich, 1982), which is the indicator of aquatic environmental pollution (Soufy et al, 2007). The vacuolization of hepatocytes might indicate an imbalance between synthesis rate of substances in parenchyma cells and their release into circulation (Ptashynski et al, 2002). The interpretation of neoplesia might be due to necrotic areas encapsulation by fibrocytes and leukocytes (Fouda and Azab, 2003). The present results agreed with others who studied the effects of different pollutants on fish liver (Fanta et al, 2003; Olojo et al, 2005; Mohamed et al, 1998).

\section{Conclusion}

This study provided data of metals levels in water and fishes in Burullus Lake and clarified effective monitoring of both environmental quality and health of the aquatic fauna and flora. Liver was the site of maximum accumulation for elements while muscle was the site of least metal accumulation. Histopathological lesions showed a reliable, easily quantifiable index of low level toxic stress to a broad range of environmental pollutants. Urban, agricultural and industrial waste discharges affect fish in Burullus Lake which reflects on human eating fish.

\section{Acknowledgement}

The authors would like to thank Mr. Ahmed EL-Sayed Zakey, Middle East Laboratory of General Authority for Fishery Resources Development, Ministry Agriculture \& Land Reclamation, Kafr-Al-Sheikh Governorate, for the kind support.

\section{References}

Abdelhamid, AM, Gomaa, AH, El-Sayed, HGM, 2013: Studies on some heavy metals in the River Nile water and fish at Helwan area, Egypt. Egypt. J. Aquat. Biol. Fish. 17, 2:105-26.

Alazemi, BM, Lewis, JW, Andrews, EB, 1996: Gill damage in the freshwater fish Ganthonemus petersii (Family: Mormyridae) exposed to se- 
lected pollutants: A structural study. Environ. Technol. 17:225-38.

Ali, OM, 1991: Study on the pollution in ElManzalah Lake. Nat. Conf., Environment of Lake El-Manzalah, Port-Said, Egypt.

El-Sadany, DFI, 2013: Effect of industrial waste discharges including heavy metals in Burullus Lake on some physiological parameters and antioxidants in Tilapia niloticus and Siluri-formes fish. New York Sci. J. 6, 4:85-92.

Barak, NA, Mason, CF, 1990: Mercury, cadmium and lead in eels and roach: The effects of size, season and locality on metal concentrations in flesh and liver. Sci. Total Environ. 92:249-56.

Barbara, J, Malgorzata, W, 2006: The metal uptake and accumulation in fish living in polluted waters. Soil and Water Pollution Monitoring Protection and Remediation, 69:107-14.

Camargo, MMP, Martinez, CBR, 2007: Histopathology of gills, kidney and liver of a Neotropical fish caged in an urban stream. Neotrop. Ichthyol. 5, 3:327-36.Porto Alegre

Damek-Proprawa, M, Sawicka-Kapusta, K, 2003: Damage to the liver, kidney and testis with reference to burden of heavy metals in yellow necked mice from areas around steel works and zinc smelters in Poland. Toxicology 186, 1/2:1-10..

Duncan, DB, 1955: Multiple range and Multiple F test. Biometric, 11:1-112.

Eid, EM, Shaltout, KH, El-Sheikh, MA, Asaeda, T, 2012: Seasonal courses of nutrients and heavy metals in water, sediment and above and belowground Typhadomingensis biomass in Lake Burullus (Egypt): Perspectives for phytoremediation:www.elsevier.com/locate/flora Flora 207:783-94.

EL-Saieed, EM, Abdel-Whahed, ZH, 1995: Effect of selenium-mercury interaction on Clarias lazera fish. Proc. $3^{\text {rd }}$ Cong., Toxicology in Developing Countries, Cairo, Egypt.

Elewa, AA, Shehata, MB, Abdel Satar, AM, Ali, MHH, Gohar, ME, 2001: Effect of the drainage water on Lake Qarun ecosystem, Egypt. The $9^{\text {th }}$ Inter. Conf. on the Conservation and Management of Lakes 11-16 November Shigha Prefectural Government, Japan.

Elghobashy, HA, Zaghloul, KH, Metwally, M AA, 2001: Effect of Some Water Pollutants on the Nile Tilapia, Oreochromis niloticus Collected from River Nile and some Egyptian Lakes. Egypt. J. Aqua. Biol. Fish 5, 4:219-50.
Fanta, E, Rios, FVSA, Rom, S, Vianna, ACC, Freiberger, S, 2003: Histopathology of the fish Corydora spaleatus contaminated with sub lethal levels of organophosphorus in water and food. Ecotoxicol. Environ. Safe 54:119-30.

Fouda, FM, Azab, AM, 2003: A comparative toxicological study on the effects of biological and chemical pesticides on the liver of Nile catfish Clarias gariepinus (Burchell, 1822). J. Egypt, Ger. Soc. Zool. 40, A:105-20.

GARFD, 2013: General Authority for Fishery Resources Development. Year-Book of Fishery: Statistics, Cairo, Egypt.

Gingerich, W, 1982: Hepatic Toxicology of Fishes. In: Weber, L.J. Ed., Aquatic Toxicology, New York Raven Press.

Hereher, ME, Salem, MI, Darwish, DH, 2010: Mapping water quality of Burullus Lagoon using remote sensing and geographic information system. J. Am. Sci. 7, 1:138-43.

Hogstrand, C, Haux, C, 2001: Binding and detoxification of heavy metals in lower vertebrates with reference to metallothionein. Comp. Biochem. Physiol. 100:137-41.

Jayakumar, N, Subburaj, A, 2017: Sub-lethal cadmium toxicity induced histopathological alterations in the gill, liver and kidney of freshwater catfish (Heteropneustes fossilis). J. Entomol. Zool. Stud. 5, 5:1339-45

Katzung, BG, 2007: Basic and Clinical Pharmacology, $10^{\text {th }}$ Edition, Boston, New York: Mc Graw Hill.

Knazicka, Z, Lukac, N, Forgacs, Z, Tvrda, E, Lukacova, J, et al, 2013: Effects of mercury on the steroidogenesis of human adreno carcinoma (NCI-H295R) cell line. J. Environ. Sci. Hlth. 48, 3:348-53.

McCarter, JA, Roch, M, 1983: Hepatic metallothionein and resistance to copper in juvenile Coho Salmon. Comp. Biochem. Physiol. 74, 1: 133-7.

Mohamed, M, Osman, M, Potter, T, Levin, R, 1998: Lead and cadmium in Nile River water and finished drinking water in Greater Cairo, Egypt. Environ. Int. 24:767-72.

Nafea, EMA, Zyada, M A, 2015: Biomonitoring of heavy metals pollution in Lake Burullus, Northern Delta, Egypt. Afr. J. Environ. Sci. Technol. 9, 1:1-7.

Nayar, S, Miller, DJ, Hunt, A, Goh, BP, Chou, LM, 2007: Environmental effects of dredging on sediment nutrients, carbon and granulom- 
etry in a Tropical Estuary. Environ. Monit. Assess. 127, 1/3: 1-13.

Okbah, MA, 2005: Nitrogen and phosphorous species of Lake Burullus water (Egypt). Egypt. J. Aqua. Res. 31:186-98.

Olojo, E, Olurin, K, Mbaka, G, Oluwemimo, A, 2005: Histopathology of the gill and liver tissues of the African catfish Clarias gariepinus exposed to lead. Afr. J. Biotechnol. 4:117-22.

Osman, AGM, Wuertz, S, Mekkawy, IAA, Verreth, J, Kirschbaum, F, 2008: Early development of the African catfish Clarias gariepinus (Burchell, 1822) focusing on the ontogeny of selected organs. J. Appl. Ichthiol. 24:187-95.

Peebua, P, Kruatrachue, M, Pokethitiyook, P, Singhakaew, S, 2008: Histopathological alterations of Nile tilapia, Oreochromis niloticus in acute and subchronic alachlor exposure. J. Environ. Biol. 29, 3:325-31.

Ptashynski, MD, Pedlar, RM, Evans, RE, Baron, CL, Klaverkamp, JF, 2002: Toxicology of dietary nickel in lake white fish (Coregonus clupeaformis). Aqua. Toxicol. (Amsterdam, Netherlands), 58, 3/4:229-47.

Ribeiro, CO, Pelletier, E, Pfeiffer, W, Rouleau, C, 2000: Comparative uptake, bioaccumulation and gill damages of inorganic mercury in tropical and nordic freshwater fish. Environ. Res. 83:286-92.

Saeed, SM, Shaker, IM, 2008: Assessment of Heavy Metals Pollution in Water and Sediments and Their Effect on Oreochromis niloticus In the Northern Delta Lakes, Egypt. $8^{\text {th }}$ International Symposium on Tilapia in Aquaculture.

Said, TO, El Moselhy, KM, Rashad AM, Shreadah, MA, 2008: Organo chlorine contaminants in water, sediment and fish of Lake Burullus, Egyptian Mediterranean Sea. Bull. Environ. Contam. Toxicol, 81:136-46.

Sandstrom, O, Larsson, A, Andersson, J, Appelberg, M, Bignert, A, Ek, H, Forlin, L, Olsson, M, 2005: Three decades Swedish experience stresses the need of integrated long-term monitoring in marine coastal areas. Water Qual. Res. J. Canada. 40, 3:233-50.

SAS (Statistical Analysis System), 2002: SAS/ STAT user's guide release 6.03 edition. SAS Institute Inc. Cary, North Carolina, USA.

Schreck, CB, Moyle, PB, 1990: Methods of Fish Biology: American Fisheries Society, Bethesda, Maryland, USA.

Sener, G, Sehirli, O, Tozan, A, Velioğlu-Ovunc, A, Gedik, N, Omurtag, GZ, 2007: Ginkgo biloba extract protects against mercury (II) induced oxidative tissue damage in rats. Food Chem. Toxicol. 45, 4:543-50.

Serov, P, Kuginis, L, Williams, JP, 2012: Risk assessment guidelines for groundwater dependent ecosystems Vol. 1- The conceptual framework. National Water Commission, Australian Government.

Sorensen, EMB, 1991: Metal Poisoning in Fish. Oxford and I. B. H Publishing Co. Bombay.

Soufy, H, Soliman, M, El-Manakhly, E, Gaafa, A, 2007: Some biochemical and pathological investigations on monosex Tilapia following chronic exposure to carbofuran pesticides. Glob. Vet. 1: 45-52.

Vander Oost, R, Beyer, J, Vermeulan, NPE, 2003: Fish bioaccumulation and biomarkers in environmental risk assessment: A review. Environ. Toxicol. Pharmacol. 13, 2:37-49.

Wang, L, Wang, Y, Xu, C, An, Z, Wang, S, 2011: Analysis and evaluation of the source of heavy metals in water of the River Changjiang. Environ. Monit. Assess. 173, 1/4:301-13.

Wetzel, RG, Likens, GE, 2006: Limnological Analysis. $3^{\text {rd }}$ ed., New York, Springer.

WHO, 2012: Guidelines for drinking water quality. Recommendations Vol. $1,2^{\text {nd }}$ ed., Geneva.

Yacoub, AM, 2007: Study on Some Heavy Metals Accumulated in Some Organs of Three River Nile Fishes from Cairo and Kalubia Governorates. Afr. J. Biol. Sci. 3: 9-21.

Fig. 1: Samples collection sites at western portion of Lake Burullus.

Fig. 2: A: Liver structure in $O$. niloticus collected from site (2) showing: congested blood vessels (CBV), hemolysis (H), and appearance of necrotic areas $(\mathrm{N})$ were observed $(\mathrm{Bar}=200 \mu \mathrm{M})$. B: Liver in C. garabinus collected from site (1) showing: congested blood vessels $(\mathrm{CBV})$, with invading of leukocytes infiltration around central vein observed $(B a r=200 \mu \mathrm{M})$. C: Liver structure in O. niloticus collected from site (3)

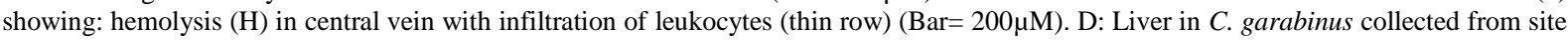
(3) showing: vasodilatation in central vein, degeneration of hepatocytes giving abnormal cells with necrotic and vacuolated areas (V) in hepatic cells and infiltration of lymphocytes observed $(\mathrm{Bar}=200 \mu \mathrm{M})$. E: Liver in O. niloticus collected from site (1) showing: no histopathological effect of hepatic cells, normal hepatic strands (HS), normal central vein $(\mathrm{CV})$ recorded $($ Bar $=200 \mu \mathrm{M})$. F: Liver in C. garabinus collected from site (2) showing: severe histopathological effect represented by abnormal appearance of the liver tissue, fibrosis $(\mathrm{F})$, invading lymphocytes or polymorph leukocytes (L), some necrotic areas encapsulated by fibrous layers and packed with aggregated lymphocytes forming neoplastic cysts $(\mathrm{C})$ observed $(\mathrm{Bar}=200 \mu \mathrm{M})$ 


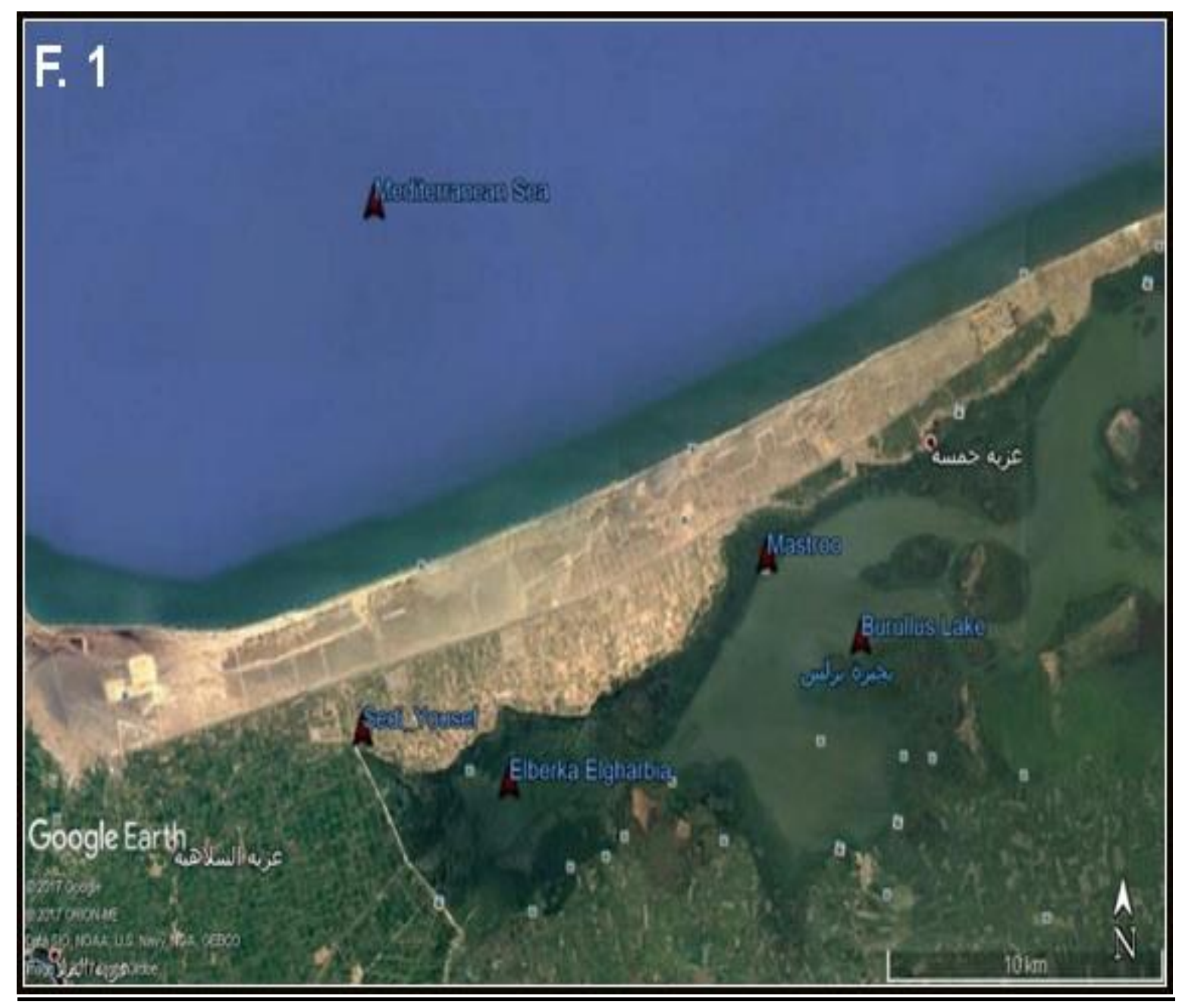




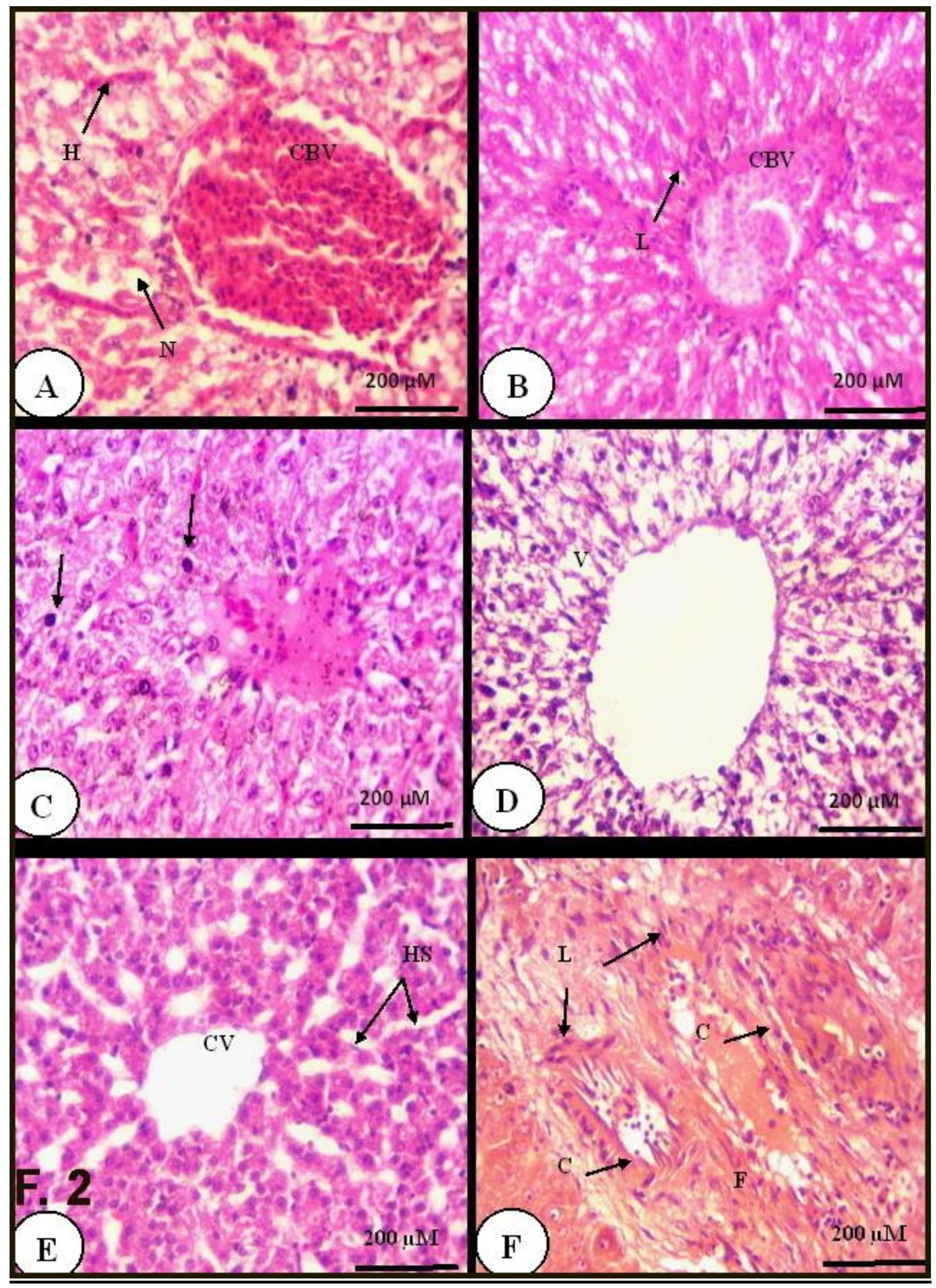

